\title{
Seroprevalence of Hepatitis B Virus Infection, Mother- To-Child Transmission, and Associated Risk Factors Among Delivering Mothers in Tigray Region, Northern Ethiopia: a Cross-Sectional Study
}

\author{
Kbrom Gemechu Kiros • Mekonnen Haftom Goyteom • Yohannes Ashebir Tesfamichael • \\ Haftea Hagos Mekonen • Tsegu Hailu Gebru • Tesfay Gebreslassie Gebrehiwot • \\ Yared Hailesilassie Teka • Woldu Aberhe Abrha · Degena Bahrey Tadesse
}

Received: August 8, 2020 / Accepted: September 3, 2020 / Published online: September 15, 2020

(C) The Author(s) 2020

\section{ABSTRACT}

Introduction: High prevalence of hepatitis B virus (HBV) infection among pregnant women is the primary source of infection for their children and the general population. Motherto-child transmission (MTCT) is the primary mode of transmission in endemic areas like Ethiopia. The aim of this study was to determine the prevalence of HBV infection, rate of MTCT, and associated risk factors among delivering mothers.

Methods: This health facility-based cross-sectional study was conducted in four public hospitals of the Eastern zone of Tigray among 473 delivering mothers. Structured questionnaires and laboratory results were used to collect the data. The data were checked for completeness and entered into EpiData manager

Digital Features To view digital features for this article go to https://doi.org/10.6084/m9.figshare.12906881.

K. G. Kiros $(\bowtie) \cdot$ M. H. Goyteom · Y.

A. Tesfamichael · H. H. Mekonen · T. H. Gebru .

T. G. Gebrehiwot . Y. H. Teka

Department of Nursing, Adigrat University, Adigrat, Ethiopia

e-mail: kbrom.gemechu@adu.edu.et;

kbromgemechu@gmail.com

W. A. Abrha · D. B. Tadesse

School of Nursing, College of Health Sciences and

Comprehensive Specialized Hospital, Aksum

University, Tigray, Ethiopia version 4.6.0.0. Then the data were exported to Statistical Package for Social Sciences (SPSS) version 23. The odds ratio, along with a 95\% confidence interval, was estimated to identify predictors of $\mathrm{HBV}$ infection using multivariable logistic regression analysis. Significant association was considered at $p<0.05$.

Results: A total of 473 mothers were enrolled, and the response rate was $100 \%$. The prevalence of HBV infection among the mothers and the rate of MTCT of the infection were $11.6 \%$ and $30.9 \%$, respectively. History of home delivery [adjusted odds ratio $(\mathrm{AOR})=4.5,95 \%$ confidence interval (CI) $(2,10.6)]$, history of hospital admission $[\mathrm{AOR}=5,95 \% \mathrm{CI}(2.2,11.5)]$, working at health facility $[\mathrm{AOR}=5.4,95 \% \mathrm{CI}(1.4$, 20.7)], body tattoos $[\mathrm{AOR}=5.8,95 \%$ CI $(2.4$, 13.6)], sharing personal care materials [AOR = 3.8, 95\% CI $(1.4,9.9)]$, insufficient knowledge $[\mathrm{AOR}=5.6,95 \%$ CI $(1.6,19)]$, and having human immunodeficiency virus (HIV) [AOR = $5.1,95 \%$ CI $(1,26.2)]$ were significantly associated with HBV infection.

Conclusion: HBV infection among delivering women is becoming highly endemic, and the rate of MTCT was high. Therefore, administering hepatitis $B$ vaccine to all neonates within $24 \mathrm{~h}$ of birth is mandatory to prevent MTCT of HBV infection and related complications. Furthermore, health education and dissemination of information about $\mathrm{HBV}$ for the pregnant mothers are needed to reduce HBV infection and vertical transmission in Ethiopia. 
Keywords: Associated factors; Hepatitis B virus; Mother-to-child transmission; Pregnant mother

\section{Key Summary Points}

\section{Why carry out this study?}

The burden of hepatitis B virus (HBV) infection is highest in sub-Saharan African countries, particularly in those with under-resourced health care systems. In Ethiopia, the prevalence of HBV infection among pregnant women ranges from $4.9 \%$ to $8.1 \%$. High prevalence of $\mathrm{HBV}$ infection among pregnant women is the primary source of infection for their children and the general population. Even though there is a high magnitude of HBV infection and mother-to-child transmission among delivering mothers in Ethiopia, it is not well studied.

\section{What was learned from the study?}

Overall, the prevalence of HBV infection and the rate of mother-to-child transmission (MTCT) among delivering women was high.

The determinant factors for the high prevalence of $\mathrm{HBV}$ infection were home delivery, hospital admission, having body tattoos, working at a health facility, sharing personal care materials, insufficient knowledge of HBV, and having human immunodeficiency virus (HIV).

Administering the hepatitis $\mathrm{B}$ vaccine to all neonates within $24 \mathrm{~h}$ of birth is mandatory to prevent MTCT of HBV infection and related complications. Furthermore, health education and dissemination of information about HBV for pregnant mothers are needed.

\section{DIGITAL FEATURES}

This article is published with digital features to facilitate understanding of the article. To view digital features for this article go to https://doi. org/10.6084/m9.figshare.12906881.

\section{INTRODUCTION}

Hepatitis B virus (HBV) infection is one of the major diseases that cause devastating public health impacts in the world. Viral hepatitis kills more people than a human immune virus and malaria, but it has received less global attention [1]. Globally, about 257 million people are chronically infected with HBV. Of those, African and Western Pacific regions contribute 68\% of the total infections. HBV infection was responsible for 887,000 deaths, mostly from cirrhosis and hepatocellular carcinoma [2]. Although there is improved childhood HBV vaccination, vertical transmission accounts for $35-40 \%$ worldwide, and about $50 \%$ of new HBV infections in high endemic countries [3].

The burden of HBV infection is highest in sub-Saharan African countries, particularly in those with under-resourced health care systems [4]. In Ethiopia, around 10 million people were infected with $\mathrm{HBV}$, and the majority of the infected population was unaware of their disease status [5].

A recent systematic review done in Ethiopia reports that the prevalence of $\mathrm{HBV}$ infection among the general population was $7.4 \%$, which classifies the country among higher to intermediate endemicity areas [6]. In Ethiopia, the prevalence of $\mathrm{HBV}$ infection among pregnant women ranges from $4.9 \%$ to $8.1 \%$, with variations among the regions [7-11].

Newborns infected with HBV through mother-to-child transmission (MTCT) have an 85-90\% risk of developing chronic HBV infection. Acute HBV infection in early pregnancy is associated with a $10 \%$ risk of prenatal transmission, but infection close to or during labor may infect more than $60 \%$ of neonates [12]. The rate of MTCT of HBV infection was not well studied in Ethiopia. However, one study done in Addis Ababa revealed that $75 \%$ of neonates born from $\mathrm{HBV}$-infected women were positive for hepatitis B surface antigen (HBsAg) [9]. Insufficient coverage of $\mathrm{HBV}$ vaccination, unsafe blood transfusion, poor prevention 
practices, and inadequate knowledge are major risk factors for HBV infection among pregnant mothers in Ethiopia [13-15].

Ethiopia is classified under the geographical regions with intermediate to hyperendemic HBV infection. However, the country's health system pays little attention to the prevention and control of viral hepatitis among pregnant women $[15,16]$. Even though the prevalence of HBV infection and the rate of MTCT are high among delivering women in Ethiopia, it is not well studied. Therefore, the study aimed to assess the prevalence of $\mathrm{HBV}$ infection, the rate MTCT, and associated factors among delivering women in health facilities of the eastern zone of Tigray.

\section{Specific Objectives}

1. To determine the magnitude of HBV infection among delivering women in Northern Ethiopia.

2. To determine the rate of transmission of HBV infection to newborn babies in Northern Ethiopia.

3. To identify the associated risk factors of HBV infection among delivering women in Northern Ethiopia.

\section{METHODS}

\section{Study Area, Design, and Participants}

The study was conducted in the eastern zone of the Tigray region. This zone is located at $898 \mathrm{~km}$ from Addis Ababa, Ethiopia's capital city, and $120 \mathrm{~km}$ from Mekelle, the capital city of the Tigray region. There are two general hospitals and seven primary hospitals in the eastern zone of Tigray. Of those, four public hospitals were selected using a simple random sampling method. The study was conducted using a hospital-based cross-sectional study design. All selected pregnant women who came for delivery to the chosen four hospitals during the study period were included and delivering mothers who were vaccinated for HBV infection were excluded from this study.

\section{Sample Size Determination and Sampling Technique}

The single population proportion formula was used. The estimated proportion was the rate of MTCT of HBV infection among delivering women in Addis Ababa, Ethiopia, which was $75 \%$ [9]. Accordingly, sample size $(n)$ was estimated with a confidence level of $95 \%$ and a $4 \%$ margin of error, and adding a 5\% non-response rate, the final sample size was 473 . The total sample was proportionally allocated to the selected hospitals. We used a systematic random sampling method to select the study participants.

\section{Data Collection Tools and Procedures}

The questionnaire was developed by reviewing different related literature $[3,9,17-21]$. It contains items regarding sociodemographic data, hospitalization-related factors, risky cultural/ behavioral factors, and HBV status of the mothers and their newborns. A structured questionnaire was used to collect the data through a face-to-face interview by eight BSc (Bachelor of Science) midwives and four BSc laboratory technologists working in the selected hospitals. Three milliliters of venous blood was obtained from the mother and newborn baby, according to the standard blood collection procedure. Finally, mothers and newborn babies who were positive for HBV were referred to senior physicians for further evaluation and treatment.

\section{Laboratory Procedure}

The blood was centrifuged for at least $10 \mathrm{~min}$ at room temperature, and the serum obtained was collected using a test tube and stored in a refrigerator $\left(-20^{\circ} \mathrm{C}\right)$. Then the serum was tested for HBsAg using HBsAg Rapid Test Cassette (Zhejiang Orient Gene Biotech Co., Ltd). Samples positive for HBV were retested by the same method, and samples repeatedly positive for HBsAg were considered as positive. 


\section{Data Quality Control}

The questionnaire was prepared in English and translated into Tigrigna language and back to English for accuracy. Two days of training were given on the objective of the study and data collection procedure for the supervisors and data collectors.

The pretest was done at Fatsi hospital on 5\% $(n=24)$ of the total sample size to check the logical sequence and consistency of the tool with the desired objectives. After the pretest, respondents were asked about the clarity of items, and then adjustments were made to the questionnaire to ensure validity. The laboratory tests were done following the standard operating procedures. The supervisor and the principal investigator supervised the implementation of the data collection procedure. The questionnaires were checked for completeness every day by the principal investigator.

\section{Operational Definitions}

\section{Level of Knowledge}

Level of knowledge was assessed on the basis of 12 knowledge questions; mothers who answered greater than $50 \%$ of knowledge-related questions were considered as having sufficient knowledge, and those who answered less than $50 \%$ were considered as having insufficient knowledge.

\section{Data Processing and Analysis}

The collected data were coded, entered, and cleaned using EpiData manager version 4.6.0.0 and exported to SPSS version 23.0/IBM software for analysis. Descriptive statistics were computed and presented using tables and texts. Binary logistic regression was used to determine the magnitude, direction, and strength of association between a set of independent variables and the dependent variable at $p<0.25$ significance level. Variables significant at $p<0.25$ with the dependent variable were selected for multivariable analysis. Odds ratio with 95\% confidence level was computed, and a significant association was declared at $p<0.05$.
Multicollinearity was assessed by a variance inflation factor to control confounders. Hosmer and Lemeshow test was used to check the goodness of fit of the model, and the model was fitted at $p=0.944$.

\section{Compliance with Ethics Guidelines}

The study was done according to the Helsinki Declaration. Ethical approvals were obtained from Adigrat University ethical review committee (ID number ADU/CMHS/086/11). An official letter was written from the Tigray regional health bureau to each hospital, and a letter of permission was obtained from the medical director's office to communicate with head nurses/midwives of the selected hospitals. The mothers were informed about the purpose, right to participate, and the confidentiality of information. Written consent was obtained from the mothers.

\section{RESULTS}

\section{Sociodemographic Characteristics}

A total of 473 delivering women and their infant cord blood samples were collected, and the response rate was $100 \%$. The mean age was 26.5 years. Thirty six point two percent of the mother's age ranged from 20 to 24 years. The majority of the mothers were orthodox followers $(90.3 \%)$ and from the Tigray region (95.8\%). Thirty five point nine percent of the study participants completed secondary school, and $74.0 \%$ of the study participants were urban residents. Forty six point one percent of the mothers were housewives. Besides, $68.3 \%$ and $61.5 \%$ of the mothers were multigravidas and multipara, respectively (Table 1).

\section{Cultural and Clinical Factors}

Out of 473 delivering mothers, $16.7 \%$ and $28.6 \%$ of the mothers had a history of unsafe abortion and circumcision, respectively. Thirteen point five percent of the mothers had a history of multiple sexual partners, and $10.4 \%$ 
Table 1 Sociodemographic characteristics of delivering mothers in Northern Ethiopia

\begin{tabular}{|c|c|c|c|}
\hline Variable & Category & $\begin{array}{l}\text { Number } \\
(n)\end{array}$ & $\begin{array}{l}\text { Percentage } \\
(\%)\end{array}$ \\
\hline \multirow[t]{4}{*}{ Age category } & $15-19$ & 32 & 6.8 \\
\hline & $20-24$ & 171 & 36.2 \\
\hline & $25-29$ & 130 & 27.5 \\
\hline & $>29[21]$ & 140 & 29.5 \\
\hline \multirow[t]{4}{*}{ Religion } & Orthodox & 427 & 90.3 \\
\hline & Protestant & 24 & 5.1 \\
\hline & Catholic & 12 & 2.5 \\
\hline & Muslim & 10 & 2.1 \\
\hline \multirow[t]{3}{*}{ Marital status } & Married & 424 & 89.6 \\
\hline & Divorced & 41 & 8.7 \\
\hline & Widowed & 8 & 1.7 \\
\hline \multirow[t]{2}{*}{ Ethnicity } & Tigray & 453 & 95.8 \\
\hline & Amhara & 20 & 4.2 \\
\hline \multirow[t]{4}{*}{$\begin{array}{l}\text { Educational } \\
\text { status }\end{array}$} & $\begin{array}{c}\text { Can not read } \\
\text { and write }\end{array}$ & 59 & 12.5 \\
\hline & $\begin{array}{l}\text { Primary } \\
\text { school }\end{array}$ & 134 & 28.3 \\
\hline & $\begin{array}{l}\text { Secondary } \\
\text { school }\end{array}$ & 170 & 35.9 \\
\hline & $\begin{array}{l}\text { Diploma and } \\
\text { above }\end{array}$ & 110 & 23.3 \\
\hline \multirow{5}{*}{$\begin{array}{l}\text { Occupational } \\
\text { status }\end{array}$} & Housewife & 218 & 46.1 \\
\hline & $\begin{array}{c}\text { Government } \\
\text { employee }\end{array}$ & 116 & 24.5 \\
\hline & Merchant & 85 & 18.0 \\
\hline & Farmer & 45 & 9.5 \\
\hline & Student & 9 & 1.9 \\
\hline \multirow{4}{*}{$\begin{array}{l}\text { Average } \\
\text { monthly } \\
\text { income }\end{array}$} & $<1000$ & 75 & 15.9 \\
\hline & $1000-1500$ & 62 & 13.1 \\
\hline & $1501-2300$ & 77 & 16.3 \\
\hline & $>2300[22]$ & 259 & 54.7 \\
\hline
\end{tabular}

Table 1 continued

\begin{tabular}{llll}
\hline Variable & Category & $\begin{array}{l}\text { Number } \\
(\boldsymbol{n})\end{array}$ & $\begin{array}{l}\text { Percentage } \\
(\%)\end{array}$ \\
\hline Residential & Urban & 350 & 74.0 \\
area & Rural & 123 & 26.0 \\
Gravidity & Primgravida & 150 & 31.7 \\
& Multigravida & 323 & 68.3 \\
Parity & 1 & 182 & 38.5 \\
& $\geq 2$ & 291 & 61.5 \\
\hline
\end{tabular}

of the mothers were sharing personal care materials. Besides, $17.3 \%$ of the mothers had a history of home delivery. Of those, $31.7 \%$ gave birth at home more than two times in their previous pregnancy. The majority (91.3\%) of the mothers had a history of antenatal care (ANC) follow-up during their current pregnancy. However, $21.8 \%$ of the mothers were not screened for HBV infection.

\section{Prevalence of HBV Infection}

The prevalence of HBV infection among delivering mothers was $11.6 \%$ [95\% CI $(8.9,14.4)]$. Mothers from rural residents had a high prevalence of $\mathrm{HBV}$ infection compared to their counterparts, $18.7 \%$ vs. $9.1 \%$. Out of all delivering mothers with HBV infection, $38.2 \%$ were among the age group of $20-24$ years, and $94.5 \%$ of them were orthodox followers. Forty seven point three percent of delivering mothers with HBV infection had completed secondary school education. Besides, $96.4 \%$ and $92.7 \%$ of the delivering mothers with $\mathrm{HBV}$ infection were from Tigray region and were married, respectively (Table 2).

\section{Rate of MTCT of HBV Infection}

The rate of MTCT of HBV infection among delivering women was 30.9\% [95\% CI (20, 43.6)]. It was higher among HIV-positive mothers $(66.7 \%)$ and mothers who had no 
Table 2 Prevalence of HBV infection among delivering women in Northern Ethiopia

\begin{tabular}{|c|c|c|c|}
\hline \multirow[t]{2}{*}{ Variable } & \multirow[t]{2}{*}{ Category } & \multicolumn{2}{|c|}{ HBV infection } \\
\hline & & $\begin{array}{l}\text { Positive } \\
n(\%)\end{array}$ & $\begin{array}{l}\text { Negative } \\
n(\%)\end{array}$ \\
\hline \multirow[t]{4}{*}{ Age category } & $15-19$ & $2(3.6)$ & $30(7.2)$ \\
\hline & $20-24$ & $21(38.2)$ & $150(35.9)$ \\
\hline & $25-29$ & $12(21.8)$ & $118(28.2)$ \\
\hline & $>29$ & $20(36.4)$ & $120(28.7)$ \\
\hline \multirow[t]{4}{*}{ Religion } & Orthodox & $52(94.5)$ & $375(89.7)$ \\
\hline & Protestant & $3(5.5)$ & $21(5.0)$ \\
\hline & Catholic & 0 & $12(2.9)$ \\
\hline & Muslim & 0 & $10(2.4)$ \\
\hline \multirow[t]{3}{*}{ Marital status } & Married & $51(92.7)$ & $373(89.2)$ \\
\hline & Divorced & $4(7.3)$ & $37(8.9)$ \\
\hline & Widowed & 0 & $8(1.9)$ \\
\hline \multirow[t]{2}{*}{ Ethnicity } & Tigray & $53(96.4)$ & $401(95.9)$ \\
\hline & Amhara & $2(3.6)$ & $17(4.1)$ \\
\hline \multirow[t]{4}{*}{$\begin{array}{l}\text { Educational } \\
\text { status }\end{array}$} & $\begin{array}{l}\text { Can not read } \\
\text { and write }\end{array}$ & $6(10.9)$ & $53(12.7)$ \\
\hline & Primary school & $9(16.4)$ & $125(29.9)$ \\
\hline & $\begin{array}{c}\text { Secondary } \\
\text { school }\end{array}$ & $26(47.3)$ & $144(34.4)$ \\
\hline & $\begin{array}{l}\text { Diploma and } \\
\text { above }\end{array}$ & $14(25.4)$ & $96(23.0)$ \\
\hline \multirow{5}{*}{$\begin{array}{l}\text { Occupational } \\
\text { status }\end{array}$} & Housewife & $27(49.1)$ & $191(45.7)$ \\
\hline & $\begin{array}{c}\text { Government } \\
\text { employee }\end{array}$ & $12(21.8)$ & $104(24.9)$ \\
\hline & Merchant & $11(20.0)$ & $74(17.7)$ \\
\hline & Farmer & $4(7.3)$ & $41(9.8)$ \\
\hline & Student & $1(1.8)$ & $8(1.9)$ \\
\hline \multirow{4}{*}{$\begin{array}{l}\text { Average } \\
\text { monthly } \\
\text { income }\end{array}$} & $<1000$ & $13(23.6)$ & $62(14.8)$ \\
\hline & $1000-1500$ & $4(7.3)$ & $58(13.9)$ \\
\hline & $1501-2300$ & $10(18.2)$ & $67(16.0)$ \\
\hline & $>2300$ & $28(50.9)$ & $231(55.3)$ \\
\hline
\end{tabular}

Table 2 continued

\begin{tabular}{llll}
\hline Variable & Category & \multicolumn{2}{l}{ HBV infection } \\
\cline { 3 - 4 } & & $\begin{array}{l}\text { Positive } \\
\boldsymbol{n}(\%)\end{array}$ & $\begin{array}{l}\text { Negative } \\
\boldsymbol{n}(\%)\end{array}$ \\
\hline Residential area & Urban & $32(58.2)$ & $318(76.1)$ \\
& Rural & $23(41.8)$ & $100(23.9)$ \\
Gravidity & Primgravida & $19(34.5)$ & $131(31.3)$ \\
& Multigravida & $36(65.5)$ & $287(68.7)$ \\
Parity & 1 & $26(47.3)$ & $156(37.3)$ \\
& $\geq 2$ & $29(52.7)$ & $262(62.7)$ \\
\hline
\end{tabular}

history of ANC follow-up (64.7\%). In this study, around $67.3 \%$ of the mothers who were positive for HBsAg were not aware of the vertical transmission of $\mathrm{HBV}$ infection. Of those, $70.6 \%$ of their newborn babies were HBsAg positive. Mothers who had insufficient knowledge about HBV infection had a high rate of MTCT (88.2\%) compared to mothers who had sufficient knowledge (22.8\%).

\section{Associated Risk Factors of HBV Infection}

Multivariable logistic regression analysis was used to determine the predictor of HBV infection among delivering mothers. Mothers who had a history of home delivery were 4.5 times more likely to have HBV infection compared to their counterparts $[\mathrm{AOR}=4.5,95 \%$ CI $\quad(2$, 10.6)]. The odds of having HBV infection were five times higher among mothers who had a history of hospital admission [AOR $=5,95 \%$ CI $(2.2,11.5)]$. Mothers working at the health facility were 5.4 times riskier for $\mathrm{HBV}$ infection $[\mathrm{AOR}=5.4,95 \%$ CI $(1.4,20.7)]$. Besides, HBV infection was 5.8 times higher among mothers who had tattoos on their bodies compared to their counterparts $[\mathrm{AOR}=5.8,95 \%$ CI $(2.4$, 13.6)].

Mothers who were sharing personal care materials such as scissors, blade, toothbrush, or others were 3.8 times more likely to have HBV infection $[\mathrm{AOR}=3.8,95 \%$ CI $(1.4,9.9)]$. The 
Table 3 Factors associated with HBV infection among delivering women in Northern Ethiopia, 2019

\begin{tabular}{|c|c|c|c|c|c|c|}
\hline \multirow[t]{2}{*}{ Variable } & \multirow[t]{2}{*}{ Category } & \multicolumn{2}{|c|}{ HBV infection } & \multirow[t]{2}{*}{ COR $(95 \% \mathrm{CI})$} & \multirow[t]{2}{*}{ AOR (95\% CI) } & \multirow[t]{2}{*}{$p$ value } \\
\hline & & Positive & Negative & & & \\
\hline \multirow[t]{2}{*}{ Home delivery } & Yes & $30(54.5)$ & $52(12.4)$ & 1 & 1 & \\
\hline & No & $25(45.5)$ & $366(87.6)$ & $8.4(4.6,15.5)$ & $4.5(2,10.6)$ & $p<0.001$ \\
\hline \multirow[t]{2}{*}{ Hospital admission history } & Yes & $35(63.6)$ & $86(20.6)$ & 1 & 1 & \\
\hline & No & $20(36.4)$ & $332(79.4)$ & $6.8(3.7,12.3)$ & $5(2.2,11.5)$ & $p<0.001$ \\
\hline \multirow[t]{2}{*}{ Body tattoos } & Yes & $31(56.4)$ & $91(21.8)$ & 1 & 1 & \\
\hline & No & $24(43.6)$ & $327(78.2)$ & $4.6(2.6,8.3)$ & $5.8(2.4,13.6)$ & $p<0.001$ \\
\hline \multirow[t]{2}{*}{ Working at the health facility } & Yes & $10(18.2)$ & $19(4.5)$ & 1 & 1 & \\
\hline & No & $45(81.8)$ & $399(95.5)$ & $4.7(2,10.7)$ & $5.4(1.4,20.7)$ & 0.014 \\
\hline \multirow[t]{2}{*}{ Sharing personal care materials } & Yes & $21(38.2)$ & $32(7.7)$ & 1 & 1 & \\
\hline & No & $34(61.8)$ & $386(92.3)$ & $7.5(3.9,14.3)$ & $3.8(1.4,9.9)$ & 0.007 \\
\hline \multirow[t]{2}{*}{ Knowledge status } & Sufficient & $5(9.1)$ & $150(35.9)$ & $5.6(2.2,14.3)$ & $5.6(1.6,19)$ & 0.006 \\
\hline & Insufficient & $50(90.9)$ & $268(64.1)$ & 1 & 1 & \\
\hline \multirow[t]{2}{*}{ HIV status of mother } & Positive & $6(10.9)$ & $13(3.1)$ & 1 & 1 & 0.049 \\
\hline & Negative & $49(89.1)$ & $405(96.9)$ & $3.8(1.4,10.5)$ & $5.1(1,26.2)$ & \\
\hline
\end{tabular}

$C O R$ crude odds ratio, $A O R$ adjusted odds ratio, $C I$ confidence interval

$p<0.05$ considered significant

odds of HBV infection among mothers who had insufficient knowledge of $\mathrm{HBV}$ infection were 5.6 times higher compared to those who had sufficient knowledge [AOR $=5.6,95 \%$ CI $(1.6$, 19)]. The odds of having HBV infection were 5.1 times higher among mothers who were HIV positive compared to HIV-negative mothers $[\mathrm{AOR}=5.1,95 \% \mathrm{CI}(1,26.2)]$ (Table 3$)$.

\section{DISCUSSION}

In our study, the overall prevalence of HBsAg among delivering women was $11.6 \%$. Of those, around $16.4 \%$ were unaware of their HBV status. According to the World Health Organization classification, the study region is classified as a highly endemic area for HBV infection [8]. This might be due to inadequate knowledge of $\mathrm{HBV}$ infection, rising prevalence of HIV infection in our country, and the lack of preventing and monitoring $\mathrm{HBV}$ infection according to national health policy $[6,23]$.

Our overall prevalence is also higher than the prevalence of HBV infection among the general population in Ethiopia, which was $7.4 \%$ [6]. This indicates that pregnant women are more liable and exposed to HBV infection compared to the general population. This might be due to their exposure to different potential risk factors. Therefore, special attention should be given to pregnant mothers to prevent and control HBV infection.

Our finding is comparable with studies conducted in Uganda (11\%), Yemen (10.8), and Nigeria (12.0\%) [24-26]. However, it is higher than in studies conducted in Dawuro zone (3.5\%), Gambela (7.9\%), Yirgalem hospital (7.2\%), and Bahir Dar (4.7\%) [18, 19, 22, 27]. The variation could be due to the difference in study participants, cultural and behavioral 
characteristics of the study participants, and level of awareness.

In this study, the rate of MTCT of HBV infection was $30.9 \%$. This is similar to that in a study conducted in Ghana (34.7\%) [28]. However, it is lower than the rate in Ethiopia, Nigeria, and Libya, where MTCT was $75.0 \%$, $51.6 \%$, and $60.9 \%$, respectively $[9,29,30]$.

Generally, MTCT of HBV infection is still high in Ethiopia. This might be due to inadequate treatment for HBsAg carrier mothers and inadequate vaccination coverage for pregnant mothers. Therefore, preventing MTCT is essential to achieving the WHO goal of HBV elimination by 2030 [31]. This can be achieved through the antiviral treatment of HBeAg-positive pregnant women and birth dose vaccination for newborns from HBsAg carrier mothers $[18,32]$. However, it is not yet implemented in Ethiopia [13]. Therefore, early recognition and treatment of HBV carrier pregnant women and introducing birth dose vaccination for newborns from $\mathrm{HBsAg}$-positive mothers will reduce MTCT in Ethiopia.

In our study, home delivery had a significant association with HBV infection. This is in agreement with the studies done in Ethiopia and Nigeria [7, 16, 33]. The reason might be due to unsafe delivery and the use of unsterilized materials during delivery by traditional birth attendants.

History of hospital admission was another significant risk factor for HBV infection. This is supported by studies conducted in Gambela, Addis Ababa, and Shashemene [27, 34, 35]. This might be due to inadequate sterilization, crosscontamination, and poor vaccination coverage of health professionals against HBV infection. Another variable that was a significant risk factor for HBV infection was a history of working at a health facility. This is in accordance with a study conducted in Iran and Nigeria [36, 37]. This might be due to occupational exposure to blood and different body fluids.

Previous studies conducted in Ethiopia and Nigeria reported that a body tattoo is a potential risk factor for HBV infection [14, 35, 38]. This is in agreement with our findings. Sharing personal care materials was another variable that had a significant association with $\mathrm{HBV}$ infection. This is in accordance with studies done in Ethiopia and Egypt $[16,39]$. This might be due to a lack of awareness of the mode of transmission of HBV infection.

Knowledge of delivering mothers was another significant risk factor for HBV infection. Around, $67.2 \%$ of the mothers had insufficient knowledge of HBV infection. This is supported by a study conducted in Hawassa, Ethiopia [18]. This insufficient knowledge of mothers on HBV infection could raise the rate of MTCT of the virus. Around $55.8 \%$ of the mothers were not aware of the transmission of HBV from mother to child. This rate is higher compared to that in a study conducted in Ghana, which revealed that $39.3 \%$ of the mothers knew that newborns are a risk for acquiring $\mathrm{HBV}$ infection from their mothers [28]. This might be due to the weak emphasis and commitment of the national health policy and health professionals to create awareness to prevent and monitor HBV infection in Ethiopia [15].

The prevalence of HBV/HIV co-infection in our study was $10.9 \%$. Our findings showed that HIV infection was significantly associated with HBV infection. This is in agreement with a study conducted in Ethiopia and Cameroon $[18,40,41]$. This might be because both HBV and HIV have a common mode of transmission.

\section{Strengths and Limitations of the Study}

- Standard and valid questionnaire used in other studies was adopted and adapted.

- Most of the previous studies were done only for those who come to ANC follow-up; however, our study includes all women who come to the delivery room.

- A confirmatory method like ELISA was not used because of the lack of laboratory setup.

- Since our study was an institutional-based study, it may lack representativeness to all pregnant mothers. 


\section{CONCLUSIONS AND RECOMMENDATIONS}

HBV infection among delivering women is becoming highly endemic, and the rate of MTCT was high. Home delivery, hospital admission, having body tattoos, working at a health facility, sharing personal care materials, insufficient knowledge of HBV, and having HIV were determinant factors for raising the prevalence of HBV infection among delivering mothers. Administering hepatitis $\mathrm{B}$ vaccine to all neonates within $24 \mathrm{~h}$ of birth is mandatory to prevent MTCT of HBV infection and related complications. Furthermore, health education and dissemination of information about HBV for the pregnant mothers are needed, giving special consideration to young women of childbearing age to reduce HBV infection and MTCT in Ethiopia. Further studies using a larger sample size will be essential to determine the significant risk factors of MTCT.

\section{ACKNOWLEDGEMENTS}

First, we thank Adigrat University, College of Medicine, and Health Sciences. We would also thank data collectors, supervisors, and authorities of the selected hospitals for their cooperation during the data collection. Finally, we would like to thank the mothers who were willing to participate in our study.

Funding. The corresponding author gets funds from Adigrat University, but the funder has no role in the design, analysis, preparation of the manuscript, and decision to publish. No Rapid Service Fee was received by the journal for the publication of this article.

Authorship. All named authors meet the International Committee of Medical Journal Editors (ICMJE) criteria for authorship for this article, take responsibility for the integrity of the work as a whole, and have given their approval for this version to be published.
Authorship Contributions. Mekonnen Haftom Goyteom, Yohannes Ashebir Tesfamichael, Haftea Hagos Mekonen, Tsegu Hailu Gebru, Tesfay Gebreslassie Gebrehiwot, Yared Hailesilassie Teka, Woldu Aberhe Abrha and Degena Bahrey Tadesse contributed equally to the manuscript.

Disclosures. Kbrom Gemechu Kiros, Mekonnen Haftom Goyteom, Yohannes Ashebir Tesfamichael, Haftea Hagos Mekonen, Tsegu Hailu Gebru, Tesfay Gebreslassie Gebrehiwot, Yared Hailesilassie Teka, Woldu Aberhe Abrha and Degena Bahrey Tadesse have nothing to disclose.

Compliance with Ethics Guidelines. The study was done according to the Helsinki Declaration. Ethical approvals were obtained from Adigrat University ethical review committee (ID number ADU/CMHS/086/11). An official letter was written from the Tigray regional health bureau to each hospital, and a letter of permission was obtained from the medical director's office to communicate with head nurses/midwives of the selected hospitals. The mothers were informed about the purpose, right to participate, and the confidentiality of information. Written consent was obtained from the mothers.

Data Availability. The data sets used and analyzed during this study are available from the corresponding author on reasonable request.

Open Access. This article is licensed under a Creative Commons Attribution-NonCommercial 4.0 International License, which permits any non-commercial use, sharing, adaptation, distribution and reproduction in any medium or format, as long as you give appropriate credit to the original author(s) and the source, provide a link to the Creative Commons licence, and indicate if changes were made. The images or other third party material in this article are included in the article's Creative Commons licence, unless indicated otherwise in a credit line to the material. If material is not included in the article's Creative Commons licence and 
your intended use is not permitted by statutory regulation or exceeds the permitted use, you will need to obtain permission directly from the copyright holder. To view a copy of this licence, visit http://creativecommons.org/licenses/by$\mathrm{nc} / 4.0 /$.

\section{REFERENCES}

1. World Health Organization. Global Hepatitis Report. https://www.who.int/hepatitis/publications/ global-hepatitis-report2017/en/. Accessed 21 Feb 2020.

2. World Health Organization. Hepatitis B key facts. https://www.who.int/news-room/fact-sheets/detail/ hepatitis-b. Accessed 21 Feb 2020.

3. Han Z, et al. Knowledge of and attitudes towards hepatitis $B$ and its transmission from mother to child among pregnant women in Guangdong Province, China. PLoS One. 2017;12(6):e0178671.

4. Geberemicheal A, et al. Seroprevalence of hepatitis B virus infections among health care workers at the Bulle Hora Woreda Governmental Health Institutions, Southern Oromia, Ethiopia. J Environ Occup Health. 2013;2(1):9-14.

5. Bane A, Patil A, Khatib M. Healthcare cost and access to care for viral hepatitis in Ethiopia. Int J Innov Appl Stud. 2014;9(4):1718.

6. Belyhun Y, et al. Hepatitis viruses in Ethiopia: a systematic review and meta-analysis. BMC Infect Dis. 2016;16(1):761.

7. Metaferia Y, et al. Seroprevalence and associated risk factors of hepatitis B virus among pregnant women in southern Ethiopia: a hospital-based cross-sectional study. Epidemiol Health. 2016;38: e2016027.

8. Seid M, Gelaw B, Assefa A. Seroprevalence of HBV and $\mathrm{HCV}$ infections among pregnant women attending antenatal care clinic at Dessie Referral Hospital Ethiopia. Adv Life Sci Health. 2014;1(2): 109-20.

9. Tegegne D, et al. Seroprevalence, and transmission of Hepatitis B virus among delivering women and they're newly born in selected health facilities, Addis Ababa, Ethiopia: a cross-sectional study. BMC Res Notes. 2014;7(1):239.

10. Mekonnen R, Admasu D, Belete M. Sero-prevalence of hepatitis B virus and associated factors among pregnant mothers attending antenatal care in public health facilities, Dire Dawa. J Med Microb Diagn. 2018;7(281):2161-07031.000281.

11. Yakasai IA, et al. Sero-prevalence of hepatitis B virus infection and its risk factors among pregnant women attending antenatal clinic at Aminu Kano Teaching Hospital, Kano, Nigeria. J Basic Clin Reprod Sci. 2012;1(1-2):49-55.

12. Moghaddasifar I, et al. Prevalence of hepatitis B virus infection among pregnant women in Iran: a systematic review and meta-analysis. Iran J Cancer Prev. 2016;9(6):e3703.

13. Shiferaw F, Letebo M, Bane A. Chronic viral hepatitis: policy, regulation, and strategies for its control and elimination in Ethiopia. BMC Public Health. 2016;16(1):769.

14. Zenebe Y, et al. Sero-prevalence and risk factors of hepatitis B virus and human immunodeficiency virus infection among pregnant women in Bahir Dar city, Northwest Ethiopia: a cross-sectional study. BMC Infect Dis. 2014;14(1):118.

15. Kebede KM, Abateneh DD, Belay AS. Hepatitis B virus infection among pregnant women in Ethiopia: a systematic review and meta-analysis of prevalence studies. BMC Infect Dis. 2018;18(1):322.

16. Molla S, Munshea A, Nibret E. Seroprevalence of hepatitis B surface antigen and anti HCV antibody and its associated risk factors among pregnant women attending maternity ward of Felege Hiwot Referral Hospital, northwest Ethiopia: a cross-sectional study. Virol J. 2015;12(1):204.

17. Yohanes T, Zerdo Z, Chufamo N. Seroprevalence and predictors of hepatitis B virus infection among pregnant women attending routine antenatal care in Arba Minch Hospital, South Ethiopia. Hepat Res Treat. 2016;2016:9290163.

18. Amsalu A, et al. Prevalence, infectivity, and associated risk factors of hepatitis B virus among pregnant women in Yirgalem Hospital, Ethiopia: implication of screening to control mother-to-child transmission. J Pregnancy. 2018;2018:8435910.

19. Chernet A, Yesuf A, Alagaw A. Seroprevalence of hepatitis B virus surface antigen and factors associated among pregnant women in Dawuro zone, SNNPR, Southwest Ethiopia: a cross-sectional study. BMC Res Notes. 2017;10(1):418.

20. Negesse ZA, Debelo DG. Seroprevalence of hepatitis B surface antigen and associated risk factors among pregnant women in Gandhi Memorial Hospital, Addis Ababa. J Public Health Epidemiol. 2019;11(6):123-9. 
21. Umare A, et al. Hepatitis B virus infections and associated factors among pregnant women attending antenatal care clinic at Deder Hospital, Eastern Ethiopia. PLoS One. 2016;11(11):e0166936.

22. Gedefaw $G$, et al. Risk factors associated with hepatitis B virus infection among pregnant women attending antenatal clinic at Felegehiwot referral hospital, Northwest Ethiopia, 2018: an institutionbased cross-sectional study. BMC Res Notes. 2019;12(1):509.

23. Kibret GD, et al. Trends and spatial distributions of HIV prevalence in Ethiopia. Infect Dis Poverty. 2019;8(1):90.

24. Bayo $\mathrm{P}$, et al. High prevalence of hepatitis $\mathrm{B}$ virus infection among pregnant women attending antenatal care: a cross-sectional study in two hospitals in northern Uganda. BMJ Open. 2014;4(11): e005889.

25. Murad EA, et al. Epidemiology of hepatitis B and hepatitis $C$ virus infections in pregnant women in Sana'a, Yemen. BMC Pregnancy Childbirth. 2013;13(1):127.

26. Mbaawuaga EM, et al. Studies on prevalence, coinfection and associated risk factors of hepatitis $B$ virus (HBV) and human immunodeficiency virus (HIV) in Benue State, Nigeria. Sci J Public Health. 2014;2(6):569-76.

27. Tanga AT, et al. Sero-prevalence of hepatitis B virus and associated factors among pregnant women in Gambella hospital, South Western Ethiopia: a facility-based cross-sectional study. BMC Infect Dis. 2019;19(1):602.

28. Dun-Dery F, et al. Assessing the knowledge of expectant mothers on mother-to-child transmission of viral hepatitis B in the Upper West region of Ghana. BMC Infect Dis. 2017;17(1):416.

29. Eke AC, et al. Prevalence, correlates, and pattern of hepatitis B surface antigen in a low resource setting. Virol J. 2011;8(1):12.

30. El-Magrahe $\mathrm{H}$, et al. Maternal and neonatal seroprevalence of hepatitis B surface antigen (HBsAg) in Tripoli, Libya. J Infect Dev Ctries. 2010;4(03): 168-70.

31. Jourdain G, Ngo-Giang-Huong N, Khamduang W. Current progress in the prevention of mother-tochild transmission of hepatitis $\mathrm{B}$ and resulting clinical and programmatic implications. Infect Drug Resist. 2019;12:977.

32. Sheng Q-J, et al. Hepatitis B virus serosurvey and awareness of mother-to-child transmission among pregnant women in Shenyang, China: an observational study. Medicine (Baltimore). 2018;97(22): e10931.

33. Oladeinde $\mathrm{BH}$, et al. Hepatitis $\mathrm{B}$ and $\mathrm{C}$ viral infections among pregnant women in a rural community of Nigeria. Int J Basic Appl Virol. 2012;1(1): $01-5$.

34. Negero A, Sisay Z, Medhin G. Prevalence of hepatitis B surface antigen (HBsAg) among visitors of Shashemene General Hospital voluntary counseling and testing center. BMC Res Notes. 2011;4(1):35.

35. Desalegn Z, et al. Hepatitis B and human immunodeficiency virus co-infection among pregnant women in a resource-limited high endemic setting, Addis Ababa, Ethiopia: implications for prevention and control measures. Euro J Med Res. 2016;21(1): 16.

36. Othman SM, Saleh AM, Shabila NP. Knowledge about hepatitis B infection among medical students in Erbil city, Iraq. Eur Sci J. 2013;3:1857-7781.

37. Omotowo I, et al. Uptake of hepatitis B vaccination and its determinants among health care workers in a tertiary health facility in Enugu, South-East, Nigeria. BMC Infect Dis. 2018;18(1):288.

38. Kolawole OM, et al. Seroprevalence of hepatitis B surface antigenemia and its effects on hematological parameters in pregnant women in Osogbo, Nigeria. Virol J. 2012;9(1):317.

39. Mortada E, et al. Prevalence of hepatitis B virus infection among Egyptian pregnant women - a single center study. Int J Trop Dis Health. 2013;3(2): 157-68.

40. Noubiap JJN, et al. Prevalence, infectivity, and correlates of hepatitis B virus infection among pregnant women in a rural district of the Far North Region of Cameroon. BMC Public Health. $2015 ; 15(1): 454$.

41. Tiruye G, Shiferaw K, Tadesse F. Seroprevalence of hepatitis $\mathrm{B}$ virus infection and associated factors among pregnant women attended antenatal care services in Harar City, Eastern Ethiopia. J Womens Health Care. 2018;7(436):2167-0420.1000436. 